\title{
Evaluation of six screening methods for detecting significant bacteriuria
}

\author{
T K SMITH, ANDREA J HUDSON, R C SPENCER Department of Bacteriology, Royal \\ Hallamshire Hospital, Sheffield
}

SUMMARY Six screening methods for the successful detection of significant bacteriuria-electrical impedance (Malthus), automated acridine-orange staining (Autotrak), particle counting (Ramus), bioluminescence, nitrite and leucocyte test strip (BM Nephur), and microscopy-were evaluated. All had excellent predictive values for a negative result $(97 \%-100 \%)$ but were less accurate in predicting a positive result $(31 \%-83 \%)$. All methods had high sensitivities $(83 \%-100 \%)$ but lower levels of specificity $(68 \%-79 \%)$. Bioluminescence was the method with the highest specificity $(79 \%)$ and the lowest rate of false positive results $(15 \%)$.

It would be inappropriate to decide on treatment and management on the basis of the positive results achieved with any of the methods evaluated, but all methods tested could be used for screening out negative results.

Hospital diagnostic laboratories investigate many thousands of urine specimens each year, but only a small proportion (about 25-30\%) are infected. ${ }^{12}$ Large amounts of both staff time and culture media are consequently expended on specimens that eventually yield insignificant growth. Conventional methods for diagnosing urinary tract infections entail the quantitative or semiquantitative culture of urine specimens on solid culture medium. ${ }^{34}$ Results are read after overnight incubation, and a pure growth of a single bacterial species in numbers of $>10^{5}$ organisms/ $\mathrm{ml}$ is accepted as indicative of infection. ${ }^{5}$

Many screening methods have been advocated for use in detecting bacteria in urine. These include measurements of bacterial adenosine tri-phosphate by luciferase, ${ }^{67}$ measurement of heat generated by metabolising organisms, ${ }^{8}$ changes in electrical impedance,,-11 automated photometric systems $s^{1213}$ which detect growth by changes in light transmission, particle counting, ${ }^{214}$ chemical analysis, ${ }^{15-17}$ fluorescence staining using acridine-orange, ${ }^{1819}$ and filter staining techniques. ${ }^{20}$

We report the results of our investigations in which we evaluated six screening methods for their ability to detect significant bacteriuria. These were the Malthus 128H growth analyser (Malthus Ltd, Stoke on Trent, England), the Autotrak (Roche Ltd, Welwyn Garden City, Hertfordshire), the Ramus 256 (Orbec Ltd,

Accepted for publication 3 March 1988
Sanderstead, Surrey), ATP bioluminescence assay using the Amerlite analyser (Amersham International Ltd, England), the Nephur test and leucocyte test strips (Boehringer-Mannheim Ltd, West Germany) and microscopy using microtitration plates. Results were directly compared with those obtained by the semiquantitative culture plate method which was the reference technique used throughout all our evaluations.

\section{Material and methods}

SEMIQUANTITATIVE CULTURE

All cultures were grown on Columbia blood and McConkey agar (Oxoid Ltd) using a standard 0.01 $\mu \mathrm{l}$ nichrome wire loop. After incubation overnight at $37^{\circ} \mathrm{C}$ in an atmosphere containing $5 \%$ carbon dioxide the plates were examined for significant bacterial growth $\left(>10^{5}\right.$ organisms $\left./ \mathrm{ml}\right)$.

\section{Detection of antibacterial activity}

All urine samples were tested for the presence of antibacterial activity by inoculating a loopful of the specimen on to blood agar based medium (Oxoid Ltd) seeded with a fully sensitive laboratory acquired strain of Klebsiella aerogenes. Zones of inhibition were found to be more distinctive using a mucoid bacterial strain.

\section{ELECTRICAL IMPEDANCE}

In this evaluation of the Malthus $128 \mathrm{H}$ system 500 consecutive urine samples were processed. ${ }^{21}$ This 
automated system of electrical impedance is controlled by an Exorcet microcomputer with peripheral units of a matrix printer and a digital plotter. The thermostatically controlled water bath contains 128 growth cells. The computer was programmed for a five hour scan and each cell was screened with a $10 \mathrm{KHz}$ signal every six minutes. Data from each cell were available on demand either on a visual display unit or on the digital plotter expressed as a growth curve. The growth cells were inoculated by "dipping" the ceramic strip containing the platinum electrode directly into the urine specimen. These ceramic strips were then replaced into the cell and connected to the apparatus by means of push-on connectors. The Malthus $128 \mathrm{H}$ can batch process up to 128 urines at any one time.

\section{ACRIDINE-ORANGE STAINING}

The Autrotrak, an automated system of the acridineorange staining method, was evaluated using 1573 urine samples. ${ }^{22}$ The Autotrak is an epifluorescence microscope system controlled by microprocessor, which automatically samples, detects, and enumerates bacteria in urine. The instrument is pre-calibrated against standard cultures of significant bacteria. Urines $(30 \mu \mathrm{l})$ are sampled and applied to the face of a moving disposable plastic tape. The specimen is heat fixed before acridine-orange is incorporated into micro-organisms and cells. An epifluorescence microscope screens the samples and the signals produced are detected by a photomultiplier. The signal handling device allows for the enumeration of bacteria.

The Autotrak can screen about 120 specimens every hour with a result-lead time of less than 60 seconds from specimen presentation to printout of results. About $1 \mathrm{ml}$ of urine is pipetted into each specimen container, which in turn is inserted into a plastic feeding chain. A maximum of 50 specimen containers can be accommodated into the feeding chain, which is automatically fed into the Autotrak from the loading stage.

\section{PARTICLE COUNTING}

The method of particle counting was evaluated by screening 1058 urines with the Orbec Ramus 256 machine. This is an automated electronic particle counter which uses a direct physical method to count and categorise particles. The urine sample is diluted with an electrolyte solution (Orbec U-lyte) and then offered to the particle counting probe. There is a small orifice (30 $\mu \mathrm{m}$ in diameter) in the glass wall of the probe. Two platinum electrodes, internal and external, are mounted on the wall and an electrical field is established between them via the electrolyte solution in the orifice. As a particle of the sample is drawn into the orifice and enters the electrical field, it displaces its own volume of electrolyte causing a change in impedance of the system. These changes are seen as pulses, the number of pulses indicating the number of particles present. The height of pulse is proportional to the volume of each particle. Thus by passing a known volume of the urine solution through the orifice the number per unit volume and the size distribution will be counted and reported. The Ramus is an automated microbiology system designed to count and categorise micro-organisms and leucocytes in urine. ${ }^{23}{ }^{24}$ It will screen urine samples for significant bacteriuria at concentrations of $>10^{5}$ organisms $/ \mathrm{ml}$. Leucocytes are counted separately and reported simultaneously as a hard copy printout. Urine $(50 \mu \mathrm{l})$ is diluted in $2.5 \mathrm{ml}$ of electrolyte solution in a U-tray designed to analyse a maximum of 32 urine samples. The U-tray is placed into the Ramus analyser unit, information entered via the keyboard, and the analysis automatically continues until all samples have been read.

\section{BIOLUMINESCENCE ASSAY}

A total of 2000 urine specimens were processed, randomly selected from those received routinely by the laboratory. The bacterial adenosine triphosphate activity (ATP) for each sample was established, all measurements being carried out in the Amerlite Analyser. This is a semiautomated luminometer developed by Amersham International UK which reads light emission from samples in wells of microtitration plates. ${ }^{25}$ For each test, $10 \mu \mathrm{l}$ of well mixed uncentrifuged urine were transferred to a microtitre well. Any non-bacterial adenosine triphosphate activity present was removed before measurements were performed, using a mixture of Triton X-100 to lyse somatic cells, thus releasing cellular ATP and apyrase (Sigma) to destroy this ATP. Triton-apyrase $(10 \mu \mathrm{l})$ mixture $(0 \cdot 2 \%)$ were added to the urine aliquot, mixed well, and incubated at room temperature for 10 minutes. The bacterial ATP was then extracted using $10 \mu \mathrm{l}$ trichloroacetic acid $(2.5 \%$, $\mathrm{pH} \mathrm{7.75)}$ and incubated for two minutes at room temperature. It was then possible to determine the amount of bacterial ATP released. Buffer $(200 \mu \mathrm{l})$ Tris (hydroxylmethyl) methylamine-ethylenediamineacetic acid were added to each well followed by $10 \mu \mathrm{l}$ of luciferin-luciferase monitoring reagent (LKBWallac). The resulting light emission was measured directly from the microtitre tray in the Amerlite Analyser. The value obtained was proportional to the amount of ATP present in the sample. A threshold level of 10 arbitary light units was established as the best cut off limit for $10^{5}$ colony forming units $/ \mathrm{ml}$ of bacteria in urine.

\section{DIP STICKS}

Chemical analysis using the BM Nephur test and leucocyte test strips were evaluated for their ability to detect significant bacteriuria. Estimation of the 
presence of leucocytes, nitrite, and blood were the variables used to screen 1000 urine specimens. Each stick was placed into the urine sample, excess urine removed, and the development of the indicator chemicals was allowed to be produced. The presence of either leucocytes, nitrite, or blood was regarded as potential indicators of infection. Reading times for each specimen were between 30-120 seconds (as per manufacturers recommendations. ${ }^{26}$ )

\section{MICROSCOPY}

A $60 \mu \mathrm{l}$ aliquot of well mixed uncentrifuged urine was withdrawn from each of the 1000 specimens processed in this evaluation. Each aliquot was placed in a flat bottomed microtitration plate and examined under a $\times 20$ objective of an inverted microscope (WillWilovert, Leitz). The presence of epithelial cells, white cells, and red blood cells were quantified and recorded for each high power field. The presence or absence of any bacteria was also recorded. For the purpose of this evaluation, specimens were classified into one of two categories, dependent on results.

Category 1 consisted of urine specimens classified as probably infected because any one of the following criteria was met: (i) $>10$ white cells for each high power field; (ii) presence of bacteria; (iii) significant numbers of red blood cells; (iv) obscure microscopythat is, debris +++ or crystals +++ .

Category 2 consisted of urine specimens classified as probably "uninfected" because all of the following criteria were satisfied: (i) $<10$ white cells in each high power field; (ii) absence of bacteria; (iii) Insignificant number of red blood cells; or (iv) $>20$ epithelial cells in each high power field (that is, gross vaginal contamination).
Results

Results from all six evaluations are expressed in terms of sensitivity, specificity, and positive and negative predictive values for ease of performance comparisons. The calculations for the above variables were calculated as follows:

$$
\text { Sensitivity }=\frac{\text { No of true positive results }}{\text { No of true positive }+ \text { No of false negative results }} \times 100
$$

$$
\text { Specificity }=\frac{\text { No of true negative results }}{\text { No of true negative }+ \text { No of false positive results }} \times 100
$$

Positive predictive

$$
\text { value }=\frac{\text { No of true positive results }}{\text { No of true positive }+ \text { No of false positive results }} \times 100
$$

$\begin{aligned} & \text { Negative predictive } \\ & \text { value }\end{aligned}=\frac{\text { No of true negative results }}{\text { No of true negative }+ \text { No of false negative results }} \times 100$

These comparisons, together with the percentages of false positive and false negative results achieved by each method are shown in table 1 . All relevant information regarding methodology is included to enable direct comparison to be made. The detailed information for the reasons why false positive results occurred in four of the methods evaluated are shown in table 2. Table 3 gives capital costs and approximate

\begin{tabular}{|c|c|c|c|c|c|c|c|c|c|c|}
\hline Method & $\begin{array}{l}\text { No of } \\
\text { urines } \\
\text { evaluated }\end{array}$ & Sensitivity & Specificity & $\begin{array}{l}\text { Positive } \\
\text { predictive } \\
\text { value }\end{array}$ & $\begin{array}{l}\text { Negative } \\
\text { predictive } \\
\text { value }\end{array}$ & $\begin{array}{l}\text { False } \\
\text { positive (\%) }\end{array}$ & $\begin{array}{l}\text { False } \\
\text { negative (\%) }\end{array}$ & $\begin{array}{l}\text { Variables } \\
\text { detected }\end{array}$ & $\begin{array}{l}\text { Screen } \\
\text { method }\end{array}$ & $\begin{array}{l}\text { Reject } \\
\text { lead-time }\end{array}$ \\
\hline Microscopy & 2500 & 94 & 77 & 47 & 97 & 22 & 0.8 & $\begin{array}{l}\text { Bacteria } \\
\text { and } \\
\text { leucocytes }\end{array}$ & $\begin{array}{l}\text { Direct } \\
\text { and } \\
\text { manual }\end{array}$ & $\begin{array}{l}30 \text { seconds } \\
\text { per urine }\end{array}$ \\
\hline \multirow{2}{*}{$\begin{array}{l}\text { Electrical } \\
\text { impedance } \\
\text { (Malthus) }\end{array}$} & \multirow{2}{*}{500} & 83 & 75 & 83 & 97 & 18 & $4 \cdot 2$ & \multirow[t]{2}{*}{ Bacteria } & \multirow{2}{*}{$\begin{array}{l}\text { Growth } \\
\text { dependant } \\
\text { Automated }\end{array}$} & \multirow{2}{*}{$\begin{array}{l}\text { Up to } \\
2.5 \text { hours } \\
2.5-5.0 \\
\text { hours }\end{array}$} \\
\hline & & 95 & 69 & 67 & 97 & 37 & 0.9 & & & \\
\hline Dip sticks & 1000 & 85 & 76 & 32 & 97 & 24 & $3 \cdot 5$ & $\begin{array}{l}\text { Leucocytes, } \\
\text { nitrite, } \\
\text { blood }\end{array}$ & $\begin{array}{l}\text { Direct } \\
\text { and } \\
\text { manual }\end{array}$ & $\begin{array}{l}30-120 \\
\text { seconds } \\
\text { per urine }\end{array}$ \\
\hline Bioluminescence & 2000 & 87 & 79 & 61 & 99 & 15 & 0.5 & Bacteria & $\begin{array}{l}\text { Direct and } \\
\text { semi- } \\
\text { automated }\end{array}$ & $\begin{array}{l}\text { Maximum } \\
\text { of } 96 \text { urines } \\
\text { in } 45\end{array}$ \\
\hline Autotrak & 1573 & 100 & 68 & 45 & 100 & 24 & $\mathbf{0}$ & Bacteria & $\begin{array}{l}\text { Direct } \\
\text { and } \\
\text { automated }\end{array}$ & $\begin{array}{l}120 \text { urines } \\
\text { per hour }\end{array}$ \\
\hline Ramus & 1058 & 90 & 76 & 31 & 98 & 22 & 1.4 & $\begin{array}{l}\text { Bacteria } \\
\text { and } \\
\text { leucocytes }\end{array}$ & $\begin{array}{l}\text { Direct } \\
\text { and } \\
\text { automated }\end{array}$ & $\begin{array}{l}45 \text { urines } \\
\text { per hour }\end{array}$ \\
\hline
\end{tabular}
revenue costs for each of the tests of all six evaluations.

Table 1 Results of evaluation of six systems 
Table 2 Major causes of false positive results (expressed as percentage)

\begin{tabular}{llllr}
\hline Variable & Autotrak & Ramus & Bioluminescence & Microscopy \\
\hline White cells & & 34 & 23 & 24 \\
Red blood cells & 45 & 12 & 28 & 5 \\
$>5$ epithelial cells/high power field & 15 & 19 & 21 & 8 \\
Growth <10 & 23 & 20 & 8 & 4 \\
Antibacterial activity & 8 & 0 & 2 & 36 \\
Fastidious organisms & & & & \\
Obscure microscopy & & & \\
\hline
\end{tabular}

\section{Discussion}

Ideally, a screening test should provide rapid clinical information and in most cases eliminate the need for quantitative culture. ${ }^{?}$

The Malthus machine can batch process 128 specimens at any one time, but it does take up to five hours to attain acceptable sensitivity limits. At the same time, however, the number of false positive results becomes unacceptable for a screening method. A screening system based on the detection of early or accelerated growth provides results on a time scale proportional to the initial microbial load and the growth rate of any urinary pathogens present. As the results show, for a screening method to be of significant advantage to the microbiologist and clinican specimen screening should be direct and non-cultural.

The Autotrak performed well in terms of sensitivities and the predictive value for negative results which were all $100 \%$, but at $24 \%$, the number of false positive results was too high. The adverse effect of the presence of epithelial cells (table 2) on the system produced $45 \%$ of these false positive results. Specimen throughput using the Autotrak is high with minimal specimen preparation time, and about 120 urines can be screened every hour using the apparatus with a result-lead time of about 60 seconds for each urine sample.

The Ramus produced similar results to the Autotrak. Sensitivity was $90 \%(1.4 \%$ false negative rate) and the predictive value of a negative result was $98 \%$. False positive results were again high at $22 \%$. Results from this evaluation showed that the Ramus counted leucocytes accurately but was less accurate in its ability to detect bacteria. ${ }^{23}$ Positive leucocyte read-

Table 3 Capital and revenue costs of systems evaluated

\begin{tabular}{lll}
\hline & $\begin{array}{l}\text { Hardware } \\
\text { cost }\end{array}$ & $\begin{array}{l}\text { Approximate cost } \\
\text { per test (pence) }\end{array}$ \\
\hline Autotrak & $£ 25000$ & 15 \\
Ramus & $£ 22500$ & 5 \\
Malthus & $£ 30000$ & 2 \\
Bioluminescence & $£ 14000$ & 1.6 \\
Test strips & $£ 2000$ & $4 \cdot 5$ \\
Microscopy & $£$ & 0.5 \\
\hline
\end{tabular}

ings were the main problem for the high number of false positive readings. This could be due to leucocyte counts being close to threshold values. Specimen throughput was an average of 45 urines in each hour with minimal sample preparation and a result-lead time of about one urine every minute. Due to probable faults in the Ramus software, however, reading difficulties occurred with negative urine readings when the result lead time could be extended for up to three minutes. A hard copy printout of RPT (repeat) was the end result in $46(4 \%)$ of the urines processed, which resulted in a considerable delay in the specimen batch screening time. Orifice blockage did occur on two occasions but was easily cleared using the "deblocking" process of the Ramus.

The ATP assay using bioluminescence was achieved in this evaluation using the Amerlite Analyser. ${ }^{25}$ Sensitivities of $98 \%$ and the predictive value of a negative result of $99 \%$ were high. False negative results were only $0.5 \%$ and the false positive results of this evaluation were only $15 \%$. Most false positive readings were caused by excessive numbers of red blood cells (table 2). The removal of all somatic ATP when excessive somatic cells are present seems to be the main problem with this method. Extractions and bioluminescence readings of ATP were all performed in the same well as the microtitre plate, which gave the minimal sample presentation time achievable with this method. A total of 96 urine samples (maximum) gives a result-lead time of about 45 minutes and was easily achieved during this evaluation.

The variables of leucocytes, nitrite, and blood concentrations estimated by chemical analysis of dip sticks to indicate significant bacteriuria proved unacceptable. Poor sensitivity ( $85 \%$ ) due to a high false negative rate of $3.5 \%$ is outside acceptable limits. The nitrite test is too insensitive as an indicator of significant bacteriuria. ${ }^{1516}$ The predictive value for a positive result was only $32 \%$ in this evaluation, caused by the poor specificity of the blood indicator test; but the predictive value for a negative result of $97 \%$ is clinically useful. ${ }^{15}$

Microscopy, as the results show, does produce a rapid accurate and inexpensive screening procedure with a sensitivity of $94 \%$ and a predictive value for a 
negative result of $97 \%$. The false positive rate is high but poor quality specimens producing obscure microscopy is a major contributory factor. Specimen throughput is about $\mathbf{3 0}$ seconds for each urine sample. Microscopical examination, however, is tiring and subjective in interpretation where about $80 \%$ of urine samples are negative.

All evaluations were compared with an overnight aerobic incubation at $37^{\circ} \mathrm{C}$ and a bacterial count of $\geqslant 10^{5}$ organisms $/ \mathrm{ml}$, according to the criteria laid down by Kass. ${ }^{5}$ We felt that this was the only way that all the screening methods could be evaluated in the same way. As a result, low counts or presence of fastidious organisms featured as negative results. Urine screening tests are not reliably sensitive below the $10^{5}$ threshold levels, ${ }^{27}$ and this may be an important limitation because some urinary tract infections are associated with relatively low concentrations of bacteriuria. This would indicate that screening tests influenced by pyuria are more sensitive for detecting low amounts of bacteriuria. ${ }^{28}$ Alternatively, in cases of suspected urinary tract infection a test for leucocytes would result in poor test specificity as these cells are often found in excessive numbers in uninfected patients and may also be absent in patients with urinary tract infection. ${ }^{29}$

Microscopy, bioluminescence, acridine-orange staining, and particle counting all showed high sensitivities $(87-100 \%)$ but variable specificities $(68 \%$ $79 \%$ ). Sensitivities from this study did not seem to be affected by the method of screening used (that is, bacteria alone compared with bacteria plus leucocytes). Bioluminescence, however, a direct method evaluated to detect bacteria alone and not bacteria and leucocytes, produced the highest specificity of $79 \%$ and the lowest false positive results (15\%).

All of the above techniques gave excellent predictive values for a negative result $(97 \%-100 \%)$ but only marginal predictive values for a positive result $(31 \%-$ $61 \%)$.

It would therefore be inappropriate to base the decision to begin treatment on the positive results achieved with any of these methods. It would also seem appropriate to use these methods to screen for negative urine samples.

General assessment of laboratory demands show the ever increasing workload to be changing in nature, requiring the screening of more potentially negative specimens. ${ }^{29}$ Current bacteriological methods are incapable of further economies without real loss of precision and reliability of the results obtained. Rapid techniques which do not depend on culture and are linked to automated apparatus could fulfil the objectives of standardisation, speed, reliability, sensitivity, specificity and the cost effectiveness required of con- temporary clinical microbiology. ${ }^{12}$ Automation could change the role of clinical microbiology from the present day confirmatory service to a proper diagnostic discipline. ${ }^{30}$

The initial capital expenditure incurred in automation will inevitably be high (table 3). Capital and revenue consequences for automation, plus regular maintenance, are all factors to be considered. These costs, however, could be offset in situations where staff recruitment is a problem. The situation for which a fully automated urine screening method could be of use is one in which the specimen quota is high (more than 300 urines every day), staff recruitment is a problem, and the incidence of disease is low. In this situation the infected patient would be correctly identified and many of the specimens from the uninfected group would be eliminated from further investigation. ${ }^{31}$ We believe that the data presented here support the conclusion to advocate screening out, without culture if possible, most of the urine specimens submitted to the laboratory.

\section{References}

1 Curtis GDW, Johnston HH, Hack AR. Automated bacteriuria screening using the Berthold LB 950 luminescence analyser. Eur $J$ Clin Microbiol 1987;6:275-80.

2 Alexander MK, Khan MS, Dow CS. Rapid screening for bacteriuria using the particle counter, pulse height analyser and computer. J Clin Pathol 1981;34:194-8.

3 Haugen J, Strom O, Ostervolb B. Bacterial counts in urine. 1. The reliability of the loop technique. Acta Pathol Microbiol Scand 1968;74:391-6.

4 Leigh DA, Williams JD. Method for the detection of significant bacteriuria. J Clin Pathol 1964;17:498-503.

5 Kass EH, Finland M. Asymptomatic infections of the urinary tract. Trans Assoc Am Physicians 1956;69:56-64.

6 Mackett D, Kessock-Philip S, Bascomb S, Easmon CSF. Evaluation of the Lumac kit for the detection of bacteriuria by bioluminescence. J Clin Pathol 1982;35:107-10.

7 Schifman RB, Weiden M, Brooker J, et al. Bacteriuria screening by direct bioluminescence assay of ATP. J Clin Microbiol 1984;20:644-8.

8 Beezer AE, Bettelheim KA, Newell RD, Stevens J. The diagnosis of bacteriuria by flow micro-calorimetry, a preliminary investigation. Science Tools 1974;21:13-5.

9 Cady P, Dufour SW, Lawless P, Nunke B, Kraeger SJ. Impedimetric screening for bacteriuria. J Clin Microbiol 1978;7:273-8.

10 Baynes NC, Comrie J, Prain JH. Detection of bacterial growth by the Malthus conductance meter. Med Lab Sci 1983;40:149-58.

11 Brown DFJ, Warner M. Impedance and conductivity methods for detecting bacteriuria. In: Tilton RG, ed. Rapid methods and automation in microbiology. Washington, DC: American Society of Microbiology 1982:171-5.

12 Pezzlo MT, Tan GL, Peterson EM, de la Maza LA. Screening of urine cultures by three automated systems. J Clin Microbiol 1982;15:468-74.

13 Pezzlo MT. Automated methods for detection of bacteriuria. Am J Med 1983;75(1B):71-8.

14 Dow CS, France AD, Khan MS, Johnson T. Particle size distribution analysis for the rapid detection of microbial infection in urine. J Clin Pathol 1979;32:386-90.

15 Juchua VS, Nauschuetz WF. Evaluation of a leucocyte esterase 
and nitrite test strip for detection of bacteriuria. Curr Microbiol 1984;11:119-22.

16 Maksen JA, Mulling D, Yun-Sik K. Predicting urine culture results: the comparative values of nitrituria, leucocyturia and microscopic bacteriuria. Lab Med 1984;15:811-4.

17 Shaw ST, Poon SY, Wong ET. "Routine urinanalysis". Is the dipstick enough? JAMA 1985;253:1596-600.

18 Manson R, Scholefield J, Johnston RJ, Scott R. The screening of more than $\mathbf{2 0 0 0}$ schoolgirls for bacteriuria using an automated fluorescence microscopy system. Urol Res 1985;13:143-8.

19 Scholefield J, Manson R, Johnston RJ, Scott R. The use of acridine-orange staining in image analysis to detect bacteriuria. Urol Res 1985;13:141-2.

20 Pfaller MA, Baum CA, Niles AC, Murray PR. Clinical laboratory evaluation of a urine screening device. $J$ Clin Microbiol 1983;18:674-9.

21 Smith TK, Eggington R, Pease AA, Harris DM, Spencer RC. Evaluation of the Malthus $128 \mathrm{H}$ microbiological growth analyser for detecting significant bacteriuria. J Clin Pathol 1985;38:926-8.

22 Spencer RC, Smith TK, Evaluation of the Autotrak system for detecting significant bacteriuria. In: Fifth International Symposium on Rapid Methods and Automation in Microbiology and Immunology, 1987. Florence: Italian Society of Microbiology, 1987.

23 Stevens M, Mitchell CJ. Bacteriuria screening by particle size analysis: preliminary evaluation. In: Fifth International Symposium on Rapid Methods and Automation in Microbiology and Immunology, 1987. Florence: Italian Society of Microbiology, 1987.
24 Dow CS, McWalter PW. Urine screening by dual parameter analysis. Abstract P90. In: Fifth International Symposium on Rapid Methods and Automation in Microbiology and Immunology, 1987. Florence: Italian Society of Microbiology, 1987.

25 Wheat PF, Oxley KM, Spencer RC, Hastings JGM. Rapid antibiotic susceptibility testing by ATP bioluminescence, assayed with a new luminometer In: Scholmerich J, ed. Bioluminescence and chemiluminescence. New perspectives, Chichester: J. Wiley, 1987:499-502.

26 Smalley DL, Dittman AN. Use of leucocyte esterase-nitrate activity as predictive assays of significant bacteriuria. $J$ Clin Microbiol 1983;18:1256-7.

27 Kellogg JA, Manzella JP, Shaffer SM, Swartz B. Clinical relevance of culture versus screens for the detection of microbial pathogens in urine. Am J Med 1987;83:739-45.

28 Stamm WE. Quantitative urine cultures revisited. Eur $J$ Clin Microbiol 1984;3:279-81.

29 Johnstone HH, Mitchell CJ, Curtis GDW. Automation in clinical microbiology; a system for urine specimens. In: Johnstone $\mathrm{HH}$, Newsom SWB, eds. Rapid methods and automation in microbiology, 2nd International Symposium. Oxford: (Europe), Learned Information 1976:210-3.

30 Isenberg HD. Automated microbiology-"prisoner of prejudice" Diagn Med 1982;5:44-52.

31 Murray PR, Smith TB, McKinney TC. Clinical evaluation of three urine screening tests. J Clin Microbiol 1987;25:467-70.

Requests for reprints to: Dr R C Spencer, Consultant Microbiologist, Royal Hallamshire Hospital, Glossop Road, Sheffield S10 2JF, England. 